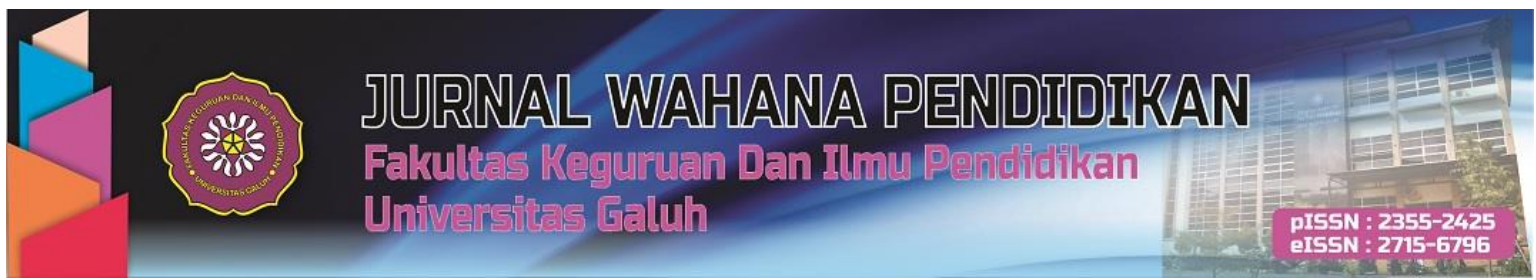

https://jurnal.unigal.ac.id/index.php/jwp

\title{
MODEL PENDIDIKAN NILAI BERBASIS KEARIFAN LOKAL PADA MASYARAKAT PENGANUT KEPERCAYAAN SUNDA WIWITAN UNTUK MENINGKATKAN KARAKTER SISWA
}

\author{
Sri Pajriah, Abdul Muin, Annisa Nurazizah Yahya, Sarah Nafiatul Janan \\ Universitas Galuh, JI. R.E. Marthadinata No. 150, Ciamis, Indonesia \\ Email: sripairiah@yahoo.co.id
}

\begin{abstract}
Character education is very important to be implemented in daily life. This is because of the problems which occur in this country. The character of the young generation is at a very critical point. The morality of this country is out of norms, ethics, religion and modest culture. The purpose of this study is to determine the effectiveness of the local wisdom-based value education model in the Sundanese Wiwitan community to improve the students' character in SMAN 1 Kawali Ciamis, Indonesia. This research was conducted using the R\&D (Research and Development) The steps of the R\&D research method are (a) potential and problems, (b) data collection, (c) product design, (d) design validation, (e) design usage, (f) trial use, (g) product revision, (h) trial run, (i) product revision, (j) mass product manufacturing. The results showed that by using the local wisdom-based value education model in Sunda Wiwitan community in Susuru sub village, Kertajaya Village, Panawangan, was very effective and feasible to be applied through integration in historical learning so that the students were able to have the following character values: religious, social, mutual cooperation, tolerance, and care for the environment to be implemented in school, family, and community life.
\end{abstract}

Keywords: Value Education, Local Wisdom, Sunda Wiwitan, Character

\section{ABSTRAK}

Pendidikan karakter sangat penting untuk diimplementasikan dalam kehidupan sehari-hari, hal ini karena adanya problem yang menimpa bangsa ini. Karakter generasi muda sudah berada pada titik yang sangat mengkhawatirkan. Moralitas bangsa ini sudah lepas dari norma, etika, agama, dan budaya luhur. Tujuan penelitian ini adalah untuk mengetahui efektifitas model pendidikan nilai berbasis kearifan lokal pada masyarakat penganut kepercayaan Sunda Wiwitan untuk meningkatkan karakter siswa di SMA Negeri 1 Kawali Ciamis. Penelitian ini dilakukan dengan menggunakan metode R\&D (Reasearchand Development) dimana metode ini menekankan pada produk akhir yang dihasilkan dari penelitian. Adapun langkah-langkah metode penelitian R\&D adalah (a) potensi dan masalah, (b) pengumpulan data, (c) desain produk, (d) validasi desain, (e) pemakaian desain, (f) ujicoba pemakaian, (g) revisiproduk, (h) uji coba pemakaian, (i) revisi produk, (j) pembuatan produk masal. Hasil penelitian menunjukkan bahwa dengan menggunakan model pendidikan nilai berbasis kearifan lokal pada masyarakat penganut kepercayaan Sunda Wiwitan di Dusun Susuru Desa Kertajaya Kecamatan Panawangan, sangat efektif dan layak untuk diterapkan melalui integrasi dalam pembelajaran sejarah sehingga siswa mampu memiliki nilai-nilai karakter sebagai berikut: religius, sosial, gotong royong, toleransi, dan peduli terhadap lingkungan untuk diimplementasikan dalam kehidupan sekolah, keluarga, dan masyarakat.

Kata kunci : Pendidikan Nilai, Kearifan Lokal, Sunda Wiwitan, Karakter

Cara sitasi:

Pajriah, S., Muin, A., Yahya, A.N., Janan, S.N. (2020) Model pendidikan nilai berbasis kearifan lokal pada masyarakat penganut kepercayaan sunda wiwitan untuk meningkatkan karakter siswa. Jurnal Wahana

Pendidikan, 7 (1), 103-112.

Sejarah Artikel: dikirim desember 2019, direvisi januari 2020, diterima januari 2020 


\section{PENDAHULUAN}

Globalisasi membawa negara-negara bangsa di dunia masuk kedalam sistem jaringan global seakan menyatu dalam satu kampung global (global vilage). Terjadinya proses perpaduan nilai bahkan terkikisnya nilai-nilai asli yang sebelumnya sakral dan menjadi identitas suatu bangsa merupakan pertukaran informasi dan nilai-nilai antar bangsa berlangsung secara cepat dan penuh dinamika. Maka, suatu bangsa harus memiliki jati diri agar bertahan dalam mengahadapi pengaruh globalisasi (Sariyatun, 2013). Datangnya kebudayaan global tersebut menimbulkan akulturasi yang tidak jarang menghempaskan nilai-nilai kebudayaan asli (lokal) dari akarnya yang kemudian menggantikan eksistensinya. Padahal, kebudayaan asing ini terkadang tidak cocok atau bahkan bertentangan dengan nilai dan norma kebudayaan lokal (Sondarika, 2019). Dalam dunia pendidikan pun mengalami krisis identitas, yaitu menurunnya nilai-nilai moral misalnya adanya sikap tidak jujur dalam ujian, adanya perkelahian antar pelajar, adanya pelecehan seksual oleh sebagian tenaga pendidik terhadap siswa didikannya, dan masalah-masalah penyimpangan lainnya (Rasyid, 2015). Pendidikan adalah jalan yang ampuh untuk melestarikan kearifan lokal karena di dalamnya terkandung nilai-nilai luhur dan dapat membentengi siswa sebagai generasi masa depan dari pengaruh negatif dari globalisasi.

Sumarmi dan Amirudin (2014), memaparkan bahwa kearifan lokal merupakan masyarakat harus memiliki pengetahuan lokal agar dimanfaatkan untuk bertahan hidup dalam suatu lingkungan yang menyatu dengan sistem kepercayaan, norma, budaya dan diekspresikan dalam tradisi dan mitos yang dianut dalam jangka waktu yang lama. Menurut Alwasilah (Hasanah, 2012), pendidikan tradisi, termasuk pendidikan budi pekerti atau karakter yang diselenggarakan oleh masyarakat adat di Indonesia sampai saat ini masih memelihara kearifan lokalnya dan terbukti ampuh dalam melaksanakan pendidikan tersebut secara baik. Pendidikan karakter merupakan upaya-upaya yang dirancang dan dilaksanakan secara sistematis untuk membantu peserta didik memahami nilai-nilai perilaku manusia yang berhubungan dengan Tuhan Yang Maha Esa, diri sendiri, sesama manusia, lingkungan, dan kebangsaan yang terwujud dalam pikiran, sikap, perasaan, perkataan, dan perbuatan berdasarkan norma-norma agama, hukum, tata krama, budaya, dan adat istiadat.

Hal ini, sebagai sebuah contoh model pendidikan berbasis kearifan lokal yang mempunyai relevansi tinggi bagi kecakapan pengembangan hidup, dengan berpijak pada pemberdayaan keterampilan serta potensi lokal pada tiap-tiap daerah (Hasanah, 2015). Dengan demikian, sangatlah tepat membangun pendidikan karakter melalui kearifan lokal. Karena, pendidikan yang mengajarkan peserta didik untuk selalu dekat dengan situasi konkret yang mereka hadapi sehari-hari melalui pendidikan berbasis kearifan lokal.

Kabupaten Ciamis yang berada di Dusun Susuru Desa Kertajaya Kecamatan Panawangan terdapat suatu komunitas masyarakat yang masih menganut kepercayaan Sunda Wiwitan. Adapun pokok ajarannya tercermin pada pandangan masyarakat dalam menjaga keserasian hubungan antara manusia dan sesamanya, lingkungan alamnya, dan Tuhannya.

Nilai-nilai kearifan lokal pada masyarakat penganut kepercayaan Sunda Wiwitan dapat dijadikan sumber dan strategis bagi pembentukan karakter. Salah satu matapelajaran yang relevan untuk mengintegrasikan pendidikan nilai atau pendidikan karakter adalah matapelajaran sejarah. Dalam pendidikan suatu bangsa, pendidikan sejarah merupakan suatu wahana penting. Alasannya menurut Hasan (2003) disebabkan adanya keyakinan bahwa materi pendidikan sejarah mampu mengembangkan sifat dan karakter generasi muda bangsa.

Penelitian ini bermaksud untuk menggali, menemukan dan merekonstruksi nilai-nilai luhur pada masyarakat penganut kepercayaan Sunda Wiwitan yang akan dikembangkan menjadi pendidikan nilai. Maka dilakukan penelitian pengembangan dengan judul "Model Pendidikan Nilai pada Masyarakat Penganut Kepercayaan Sunda Wiwitan untuk Meningkatkan Karakter Siswa di SMA Negeri 1 Kawali Ciamis".

Berdasarkan latar belakang di atas maka, rumusan masalah dalam penelitian ini adalah: 
1. Bagaimanakah proses pembelajaran sejarah yang berlangsung selama ini di SMA Negeri 1 Kawali Ciamis, khususnya mengenai pendidikan nilai dalam pembelajarannya?

2. Bagaimanakah pengembangan pendidikan nilai dengan memanfaatkan kearifan lokal pada masyarakat penganut kepercayaan Sunda Wiwitan untuk meningkatkan karakter siswa?

3. Bagaimanakah implementasi pendidikan nilai dengan memanfaatkan kearifan lokal pada masyarakat penganut kepercayaan Sunda Wiwitan untuk meningkatkan karakter siswa?

Berdasarkan rumusan masalah di atas maka, penyusun mempunyai beberapa tujuan dalam penelitian ini adalah:

1. Mendeskripsikan proses pembelajaran sejarah yang berlangsung selama ini di SMA Negeri 1 Kawali Ciamis, khususnya mengenai pendidikan nilai dalam pembelajarannya.

2. Menganalisis pengembangan pendidikan nilai dengan memanfaatkan kearifan lokal pada masyarakat penganut kepercayaan Sunda Wiwitan untuk meningkatkan karakter siswa.

3. Mengimplementasikan pengembangan pendidikan nilai dengan memanfaatkan kearifan lokal pada masyarakat penganut kepercayaan Sunda Wiwitan untuk meningkatkan karakter siswa.

Pentingnya pendidikan nilai berbasis kearifan lokal pada penganut kepercayaan Sunda Wiwitan untuk meningkatkan karakter siswa di SMA Negeri 1 Kawali Ciamis didasarkan pada asumsi bahwa:

1. Warisan budaya merupakan komponen pendidikan yang dapat menumbuhkan rasa memiliki dan apresiasi terhadap sejarah budaya sendiri.

2. Masyarakat penganut kepercayaan Sunda Wiwitan memiliki ajaran dan nilai-nilai yang mengandung "tuntutan dan tuntunan" dalam hubungan manusia dengan Tuhan, sesama manusia dan manusia dengan alam sekitarnya.

3. Nilai-nilai budaya lokal penganut kepercayaan Sunda Wiwitan sebagai filter dalam menghadapi pengaruh negatif dari globalisasi dan untuk menguatkan karakter dan jati diri bangsa.

Temuan yang ditargetkan yaitu masyarakat penganut kepercayaan Sunda Wiwitan memiliki ajaran dan nilai-nilai yang mengandung "tuntutan dan tuntunan" dalam hubungan manusia dengan Tuhan, sesama manusia dan manusia dengan alam sekitarnya. Targetnya akan menemukan model pendidikan nilai berbasis kearifan lokal pada masyarakat penganut kepercayaan Sunda Wiwitan untuk meningkatkan karakter siswa dalam pembelajaran sejarah di SMA Negeri 1 Kawali Ciamis.

Hasil penelitian ini diharapkan berguna baik secara teoritis maupun praktis. Manfaat secara teoritis adalah pengembangan ilmu yang relevan dengan masalah penelitian. Secara khusus penelitian ini sangat berguna bagi beberapa pihak antara lain:

1. Bagi pemerintah, sebagai ide dasar yang memberikan kontribusi dalam pendidikan karakter dan pembentukan karakter bangsa yang sedang digiatkan oleh Pemerintah Republik Indonesia dan agar pemerintah dapat menyadari akan arti penting keanekaragaman suku bangsa dan budayanya masing-masing.

2. Bagi pendidik, model pembelajaran yang dirumuskan dapat dijadikan pedoman dalam mengimplementasikan pendidikan nilai di sekolah.

3. Bagi siswa, menumbuhkan apresiasi dan kreasi siswa sehingga melalui model pendidikan nilai berbasis kearifan lokal dapat meningkatkan karakter dan jati diri bangsa.

4. Bagi masyarakat, memberikan masukan yang positif kepada masyarakat akan arti pentingnya potensi kebudayaan lokal dalam membentuk karakter bangsa.

\section{METODE PENELITIAN}

Penelitian ini dilakukan di SMA Negeri 1 Kawali Ciamis dengan menggunakan metode penelitian yang bersifat pengembangan (Research And Development), yaitu suatu penelitian yang ditindaklanjuti dengan pengembangan melalui proses studi lapangan, pengembangan desain model, uji coba desain model serta validasi model dalam suatu siklus yang sistematis. Cara menghimpun data dicapai dengan antara lain : (1) sumber informan (2) sumber lokasi dan sumber peristiwa, serta (3) sumber dokumentasi/arsip yang ada. Untuk menggali data dari berbagai sumber di atas dilakukan 
dengan (1) wawancara mendalam, (2) pengamatan langsung, dan (3) analisis isi data-data dokumen/arsip.

\section{HASIL DAN PEMBAHASAN}

SMA Negeri I Kawali berada di Jalan Poronggol Raya No. 9, RT 03 RW Kecamatan Kawali Kabupaten Ciamis Provinsi Jawa Barat. SMA Negeri I Kawali memiliki visi: unggul dalam prestasi, professional dalam pelayanan, bernuansa Islam. Sedangkan misinya adalah meningkatkan mutu serta efektifitas sumber daya, merealisasikan kurikulum secara optimal, melaksanakan pelayanan secara berkesinambungan, memberikan pelayanan bernuansa Islami.

Proses pembelajaran sejarah yang berlangsung selama ini di SMA Negeri 1 Kawali Ciamis, khususnya mengenai pendidikan nilai dalam pembelajaran sejarah. Berdasarkan hasil observasi sebagai berikut:

Siswa SMA Negeri I Kawali dituntut untuk dapat memiliki kemantapan aqidah dan kekhusu'an ibadah (spriritual quotient), keluasan IPTEK (Intelegency quotient), dan keluhuran akhlak (emotional quotient). Hal ini, dapat buktikan pada proses pembelajaran diawali setiap kali masuk kelas sebagai pembuka pembelajaran, siswa selalu dibiasakan untuk berdo'a dan dilanjutkan dengan tadarus alQur'an secara bersama-sama. Begitu juga ketika pada saat sebelum pulang sekolah, siswa dibiasakan untuk berdo'a dan membaca Asmaul Husna secara bersama-sama serta sholat dzuhur berjamaah.

Secara umum kurikulum yang digunakan di Sekolah SMA N 1 Kawali sebagai objek peneliti menggunakan kurikulum 2013. Dalam rencana pelaksaaan pembelajaran (RPP), berdasarkan hasil penelitian bahwa guru belum mengintegrasikan kearifan lokal sebagai sumber pendidikan karakter siswa dalam pembelajaran sejarah.

Kegiatan proses pembelajaran sejarah di dalam kelas kurang variatif karena metode konvensional masih digunakan yaitu ceramah dan diskusi, sehingga siswa dalam menerima materi pelajaran sejarah kurang menarik, membosankan bahkan tidak termotivasi untuk berfikir kritis dan kreatif dalam pembelajaran sejarah.

Selanjutnya, sarana pembelajaran sangat penting untuk mencapai tujuan pembelajaran. Ada beberapa faktor untuk menunjang keberhasilan dalam pendidikan diantaranya kurikulum, materi, media, dan lingkungan, serta kegiatan penunjang yang dapat dilaksanakan di sekolah seperti kokurikuler dan ekstrakurikuler. Kegiatan ko-kurikuler dan ekstrakurikuler memiliki keterkaitan dan sangat menunjang untuk mencapai tujuan, sehingga siswa akan lebih memahami apa yang dipelajari dalam kegiatan intrakurikuler. Terkait kegiatan ko-kurikuler biasanya dituangkan dalam bentuk pekerjaan rumah atau penugasan. Materi yang diberikan penugasan kepada siswa disesuaikan dengan matapelajarannya. Berdasarkan progam sekolah, SMA N I Kawali melakukan kegiatan kokurikuler untuk kelas XI yaitu siswa belajar langsung ke lapangan. Hanya saja, kegiatan tersebut belum memanfaatkan lingkungan terdekat siswa seperti situs-situs, komunitas adat, dan kearifan lokal sebagai sumber belajar dan basis bagi pembentukan karakter siswa.

Pengembangan pendidikan nilai dengan memanfaatkan kearifan lokal pada masyarakat penganut kepercayaan Sunda Wiwitan untuk meningkatkan karakter siswa.

Di Kabupaten Ciamis tepatnya di Dusun Susuru Desa Kertajaya Kecamatan Panawangan terdapat suatu komunitas masyarakat yang masih menganut kepercayaan Sunda Wiwitan. Sunda Wiwitan terdiri atas dua kata: Sunda dan Wiwitan. Istilah 'Sunda' (menurut P. Djatikusumah) dimaknai dalam tiga kategori konseptual dasar, yaitu: (1) filosofis: Sunda berarti bodas (putih), bersih, cahaya, indah, bagus, cantik, baik dan seterusnya; (2) etnis: Sunda berarti atau merujuk pada komunitas masyarakat suku bangsa Sunda yangTuhan ciptakan seperti halnya suku dan bangsa lain di muka bumi. Dalam hal ini berkaitan dengan kebudayaan Sunda yang melekat pada cara dan ciri manusia Sunda; (3) geografis: Sunda berarti mengacu sebagai penamaan suatu wilayah berdasarkan peta dunia sejak masa lalu terhadap wilayah Indonesia (Nusantara), yaitu sebagai tataran wilayah 'Sunda Besar' (The Greater Sunda Islands) meliputi himpunan pulau yang berukuran besar (Sumatera, Jawa, 
Madura, Kalimantan) dan 'Sunda Kecil' (The Lesser Sunda Islands), yaitu deretan pulau yang berukuran lebih kecil dan terletak di sebelah timur Pulau Jawa (Bali, Lombok, Flores, Sumbawa, Sumba, Roti, dan lain-lain) (Indrawardana, 2014:109).

Beberapa data mengungkapkan sebutan-sebutan terhadap yang disembah dan diyakini dalam sistem kepercayaan masyarakat Sunda masa lalu, seperti Hiang atau Hyang, Hyang Tunggal, Batara Tunggal, Nu Ngersakeun, Gusti Pangeran Sikang sawiji-wiji, dan sebagainya. Menurut Kartakusuma (2006:264), Hyang sebagai istilah kuno yang umum sampai sekarang digunakan dalam penyebutan kepada Sang Maha Pencipta Alam Raya beserta isinya ini adalah unsur yang tanpa wujud atau supranatural. la tidak dapat dilihat dengan mata telanjang, tetapi melalui rasa yang telah atis ("bati peureu tinggal nu atis tina rasa", perilaku tapa guna menghilangkan segala kotoran (noda) yang melekat pada fisik dan jiwa, layaknya melepas karat pada besi sehingga kian lama kian jernih dan bersih (suci) dan tiba pada hakikat kehiduan sejati). Wujud yang tertinggi itu dilambangkan dengan bentuk yang sesuai dengan kebutuhan, kepercayaan, dan kemampuan manusia itu sendiri (pendukung budaya).

Dasar religi masyarakat Baduy sama seperti halnya pada masyarakat kepercayaan Sunda Wiwitan di Dusun Susuru Desa Kertajaya Kecamatan Panawangan, dalam ajaran Sunda Wiwitan adalah kepercayaan yang bersifat monoteistis, penghormatan kepada roh nenek moyang, dan kepercayaan kepada satu kekuasaan yakni Sanghyang Keresa (Yang Maha Kuasa), yang disebut juga Batara Tunggal (Yang Maha Esa), Batara Jagat (Penguasa Alam), dan Batara Seda Niskala (Yang Maha Gaib),serta yang bersemayam di Buwana Nyungcung (Buana Atas). Orientasi, konsep, dan pengamalan keagamaan ditujukan kepada pikukuh (pedoman atau aturan) untuk menyejahterakan kehidupan di jagat mahpar (dunia ramai). Dalam dimensi sebagai manusia sakti, Batara Tunggal memiliki keturunan tujuh orang batara yang dikirimkan kedunia melalui Kabuyutan (wilayah yang disakralkan dalam komunitas Baduy); "titik awal bumi" ialah Sasaka Pusaka Buana. Konsep buwana bagi orang Baduy berkaitan dengan titik awal perjalanan dan tempat akhir kehidupan (Garna, 1994: 57). Dasar etis "agama wiwitan" Sunda Wiwitan itu tercermin pada pandangan orang baduy dalam memelihara keseimbangan hubungan antara manusia dengan sesamanya,lingkungan alamnya, dan Tuhan (Indrawardana, 2014:113).

Nilai-nilai kearifan lokal pada masyarakat penganut kepercayaan Sunda Wiwitan dapat dijadikan sumber dan strategis bagi pembentukan karakter. Salah satu matapelajaran yang relevan untuk mengintegrasikan pendidikan nilai atau pendidikan karakter adalah matapelajaran sejarah.

Sebagaimana dijelaskan Khan (2010: 2), terdapat empat jenis karakter yang selama ini dikenal dan dilaksanakan dalam proses pendidikan yaitu pendidikan karakter berbasis nilai religius, berbasis nilai budaya, berbasis lingkungan dan berbasis potensi diri.

Pendidikan sejarah merupakan suatu wahana penting. Alasannya menurut Hasan (2003) disebabkan adanya keyakinan bahwa materi pendidikan sejarah mampu mengembangkan sifat dan karakter generasi muda bangsa.

Dalam proses pengembangan penelitian ini, tentunya spesifikasi yang dihasilkan adalah model pendidikan nilai/karakter berbasis kearifan lokal dalam pembelajaran sejarah. Pembelajaran sejarah dilaksanakan di kelas X IPA dengan dua kali pertemuan pada materi Kerajaan Maritim Hindu Budha. Pada pertemuan pertama dilaksanakan di kelas, pembelajaran pendidikan nilai berbasis kearifan lokal terintegrasi pada mata pelajaran sejarah materi Kerajaan Maritim Hindu Budha dengan menyisipkan nilai-nilai kearifan lokal pada masyarakat penganut kepercayaan Sunda Wiwitan. Pertemuan kedua, pembelajaran dilaksanakan di luar kelas dengan mengajak siswa ke lapangan untuk mengamati secara langsung pada masyarakat penganut kepercayaan Sunda Wiwitan.

Adapun, kerangka teoritis dalam pengembangan model pendidikan nilai berbasis kearifan lokal ini ialah proses pembelajaran pendidikan sejarah yang bersifat konstruktivisme. Belajar dalam pandangan ahli konstruktivistik terkait dengan pengalaman yang dimiliki oleh individu. Berdasarkan pandangan ini, maka tugas seorang individu adalah menciptakan lingkungan belajar, yang sering diistilahkan sebagai "scenario of problems", yang mencerminkan adanya pengalaman belajar yang 
otentik atau nyata dan dapat diaplikasikan dalam sebuah situasi (Dick \& Carey, 2006). Peristiwa belajar akan berlangsung lebih efektif jika siswa berhubungan langsung dengan objek yang sedang dipelajari, yang ada di lingkungan sekitar (Pribadi, 2009: 138)

Dalam konteks ini, siswa akan mendapatkan pengetahuan dan pemahaman serta keterampilan tentang pengembangkan pendidikan nilai melalui pengamatan secara langsung dan pengalaman sendiri pada masyarakat kepercayaan Sunda Wiwitan yang memiliki ajaran untuk memelihara keseimbangan hubungan antara manusia dengan sesamanya, lingkungan alamnya, dan Tuhannya sebagai acuan pendidikan nilai.

Cruickshank, dkk (2006: p. 257), mengemukakan beberapa langkah yang perlu dilakukan dalam menerapkan pendekatan konstruktivistik dalam pembelajaran. Langkah-langkah tersebut dapat diwujudkan melalui beberapa tahapan yaitu: persiapan, (preparation), penyampaian materi (delivery), penutupan (closing).

Tahap persiapan yang dilakukan dalam mengimplementasikan pendekatan konstruktivistik dalam pembelajaran terdiri dari beberapa kegiatan yaitu: (1) menentukan tujuan pembelajaran; menjelaskan cara untuk mencapai tujuan pembelajaran; menjeaskan bagaimana mengelompokkan materi pelajaran; memberitahukan bagaimana cara mengaitkan informasi baru dengan informasi yang telah dimiliki sebelumnya; mengumpulkan bahan-bahan informasi yang berguna; menjelaskan bagaimana cara melakukan fefleksi.

Adapun, penyusunan model pembelajaran pendidikan nilai berbasis kearifan lokal pada masyarakat penganut kepercayaan Sunda Wiwitan terintegrasi dalam pembelajaran sejarah dilaksanakan dengan menggunakan beberapa langkah sebagai berikut: (1) mengidentifikasi pengetahuan dan pemahaman guru tentang pendidikan nilai dan nilai-nilai yang bersumber pada masyarakat penganut kepercayaan Sunda Wiwitan; (2) mengidentifikasi pemahaman dan kemampuan guru dalam menyususn rencana pembelajaran dan pelaksanaan pembelajaran; (3) menyusun strategi model pembelajaran pendidikan nilai berbasis kearifan lokal pada masyarakat penganut kepercayaan Sunda Wiwitan dengan kepala sekolah, wakil kepala sekolah bagian kurikulum, guru bimbingan konseling, guru sejarah, dan guru-guru bidang studi lainnya; (4) penjelasan mengenai tujuan pembelajaran pendidilai nilai berbasis kearifan lokal pada masyarakat penganut kepercayaan Sunda Wiwitan; (5) kesepakatan model pendidikan nilai yang dirumuskan; (6) analisis terhadap model pembelajaran pendidikan nilai secara bersama-sama; (7) model pendidikan nilai berbasis kearifan lokal pada masyarakat penganut kepercayaan Sunda Wiwitan dalam pembelajaran sejarah untuk penguatan karakter siswa (Sariyatun, 2013: 238).

Dalam konteks ini, untuk mengevaluasi model pembelajaran yang telah diproduksi maka dilakukan validasi oleh ahli materi dan model pembelajaran. Dalam penelitian ini sebagai validatornya adalah (1). Aan Suryana S.Pd., M.Pd. sebagai penguji materi (2). Guru Sejarah (3). Guru BK (4). Mia Trismiati S.Pd. sebagai penguji materi.

Tabel 1

Hasil Validasi Ahli Materi

\begin{tabular}{|c|c|c|c|c|c|c|}
\hline \multirow{2}{*}{ No } & \multirow{2}{*}{ Aspek Penilaian } & \multicolumn{5}{|c|}{ Skor } \\
\hline & & 1 & 2 & 3 & 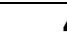 & 5 \\
\hline 1. & $\begin{array}{l}\text { Kesesuaian isi materi dengan tujuan } \\
\text { pembelajaran }\end{array}$ & & & \multicolumn{3}{|c|}{$\checkmark$} \\
\hline 2. & $\begin{array}{l}\text { Kesesuaian isi materi dengan tingkat } \\
\text { pendidikan }\end{array}$ & & & \multirow{2}{*}{\multicolumn{3}{|c|}{$\checkmark$}} \\
\hline & $\begin{array}{l}\text { Kesesuaian materi dengan pendidikan } \\
\text { karakter yang diterpkan }\end{array}$ & & & & & \\
\hline \multicolumn{2}{|c|}{ Jumlah } & & & \multicolumn{2}{|r|}{2} & 1 \\
\hline \multicolumn{2}{|c|}{ Jumlah x Skor } & & & & \multirow{4}{*}{\multicolumn{2}{|c|}{$1 \times 5$}} \\
\hline \multicolumn{2}{|c|}{ Jumlah Total } & 13 & & & & \\
\hline Rer & & 4,3 & & & & \\
\hline \multicolumn{2}{|c|}{ Keterangan } & Baik & & & & \\
\hline
\end{tabular}

Validasi oleh Aan Suryana S.Pd., M.Pd. 
Hasil validasi dari ahli materi model pembelajaran ini mempunyai jumlah total nilai 4,3 dan secara keseluruhan dinyatakan Baik dan layak diterapkan dalam proses pembelajaran. Analisis data oleh ahli materi adalah bertujuan untuk mengetahui kelayakan model yang akan diterapkan dalam proses pembelajaran. Berdasarkan penilaian dari aspek penilaian kesesuaian isi materi dengan tujuan pembelajaran, dan pendidikan karakter dengan isi materi, dari ahli materi diperoleh rerata 4,3. Ini menunjukkan bahwa model pembelajaran yang dikembangkan mempunyai kategori Baik.

Tabel 2

Hasil Validasi Ahli Model dan Desain Pembelajaran

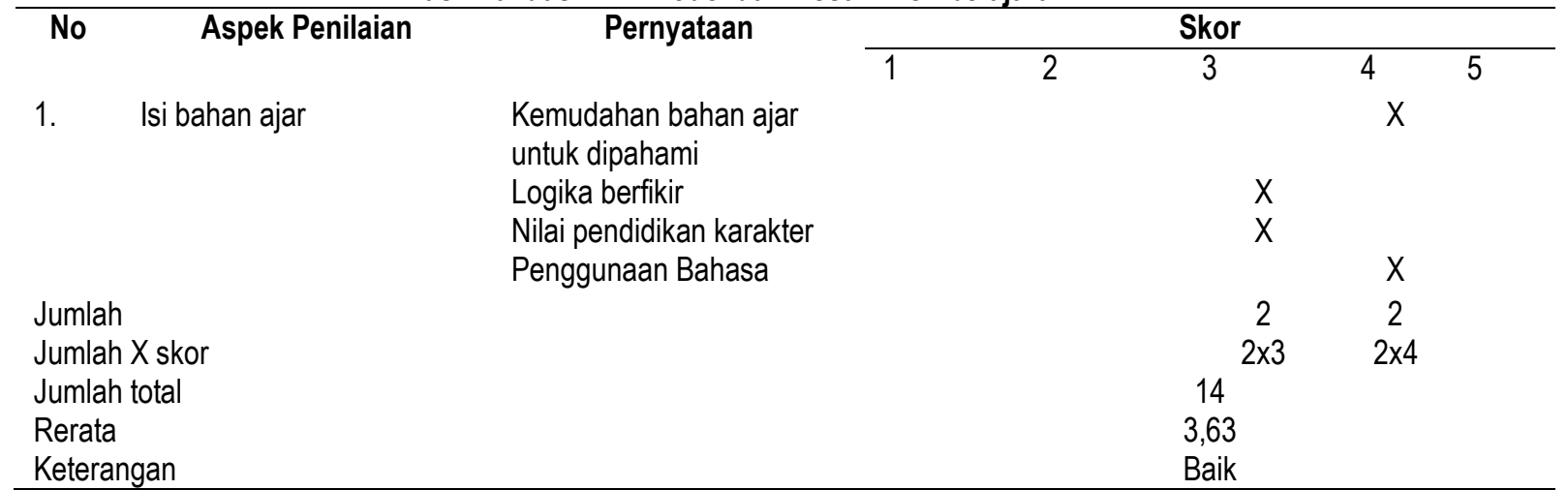

Sumber: Kuesioner Uji Coba Ahli Bahan Ajar dan Desain Pembelajaran (Validasi dilakukan oleh Guru BK dan Guru Sejarah)

Berdasarkan tabel di atas menunjukkan hasil validasi ahli bahan ajar dan desain pembelajaran mempunyai jumlah total nilai 14 dengan rerata 3,63 dan hal ini dinyatakan baik dan layak diterapkan dalam proses pembelajaran.

Adapun hasil uji coba dilapangan sebesar 75\% siswa kelas X IPA SMA N 1 Kawali ini menunjukkan bahwa model pendidikan nilai yang dikembangkan peneliti adalah cukup baik dan layak digunakan berdasarkan hasil penilaian siswa. Hal ini, dapat dilihat dari hasil yang diperoleh.

Efektifitas pengembangan model pendidikan nilai berbasis kearifan lokal pada masyarakat penganut kepercayaan Sunda Wiwitan dapat dikatakan berhasil. Hal ini, tercermin pembelajaran sejarah dengan membawa siswa melihat secara langsung dalam kehidupan masyarakat penganut kepercayaan Sunda Wiwitan yang ada di Dusun Susuru Desa Kertajaya Kecamatan Panawangan, sehingga siswa memperoleh pendidikan nilai/karakter melalui pengamatan, bertanya secara langsung dan merasakan kehidupan masyarakat penganut kepercayaan Sunda Wiwitan secara nyata dalam kehidupannya.

Implementasi pendekatan konstruktivistik dalam kegiatan pembelajaran memerlukan keaktifan siswa untuk selalu bertanya, menganalisis, menafsirkan, memprediksi dan menguji pemahaman terhadap konsep-konsep yang sedang dipelajari. Peran guru atau instruktur dalam hal ini menjadi fasilitator yang dalam mendorong proses konstruksi pengetahuan dalam diri siswa (Pribadi, 2009:143).

Sebagaimana dijelaskan Munip dalam Sirnayatin (2017:313), pendidikan karakter membutuhkan teladan hidup (living model) yang hanya bisa ditemukan dalam pribadi para guru khususnya guru sejarah Pendidikan karakter pada pembelajaran sejarah memerlukan guru yang dapat menyampaikan makna atau nilai-nilai yang terkadung di dalamnya. Karena tanpa guru, dalam hal ini guru sejarah perlu menggali kembali nilai-nilai yang ada pada pembelajaran sejarah sebagai pijakan untuk menumbuhkan dan mengembangkan karakter bangsa yang sudah pudar.

Berdasarkan hasil analisis pembelajaran sejarah dengan mengintegrasikan materi kearifan lokal pada masyarakat penganut kepercayaan Sunda Wiwitan sebagai basis pendidikan nilai bagi siswa kelas X di SMA Negeri I Kawali Ciamis yang dapat ditranmisikan kepada peserta untuk membentuk karakter dalam kehidupan di sekolah, keluarga, dan masyarakat adalah sebagai berikut:

Nilai religius: Masyarakat penganut kepercayaan sunda Wiwitan sebagai penganut kepercayaan yang taat dalam beribadah dan mereka percaya bahwa hidup di dunia ini sebagai perantara untuk kehidupan yang sesungguhnya kebahagiaan yang hakiki. Siswapun menjadi taat 
dalam beribadah, tercermin dalam pelaksanaan proses pembelajaran sejarah selalu diawali dan diakhiri dengan berdo'a.

Nilai sosial: Adapun hubungan antara manusia dengan sesama manusia dalam masyarakat sunda, menurut Masduki (2015:299), pada dasarnya harus dilandasi oleh sikap "silih asih, silih asah, dan silih asuh". Artinya harus saling mengasihi, saling mengasah atau mengajari, dan saling mengasuh sehingga tercipta suasana kehidupan masyarakat yang diwarnai keakraban, kerukunan dan kedamaian, ketentraman, dan kekeluargaan. Hal ini, tercermin dalam kegiatan pembelajaran sejarah, siswa selalu mengasihi terhadap sesama temannya, memberikan bantuan pada temannya yang memerlukan pertolongan, mengajari temannya yang belum paham dalam menerima materi pelajarannya.

Nilai gotong royong: Masyarakat penganut kepercayaan Sunda Wiwitan dalam melakukan kegiatan ritual keagamaan, membangun rumah warga ataupun rumah ibadah dilakukan secara bergotong royong, bahu membahu dengan warga setempat untuk menyelesaikan pekerjaan tersebut sehingga memperoleh hasil yang maksimal sesuai tujuan. Dalam hal ini, siswa bersama teman yang lainnya lebih giat untuk selalu membersihkan kelasnya dengan bergotong royong ataupun mengerjakan tugas kelompoknya secara bersama-sama.

Nilai Toleransi: Di sekitar masyarakat penganut kepercayaan Sunda Wiwitan, terdapat juga agama lainnya seperti agama Islam dan Kristen. Keadaan seperti ini, pentingnya untuk menjunjung tinggi nilai toleransi kehidupan beragama sesuai dengan kepercayaan masing-masing. Sikap toleransi harus terjalin, ketika teman sekelas ada yang berbeda keyakinan dalam beragama dengan memberikan kesempatan untuk beribadah sesuai dengan keyakinannya masing-masing, dalam diskusi kelompok di kelaspun ketika ada yang tidak sependapat agar tetap menghargai pendapat orang lain.

Nilai peduli terhadap lingkungan: Masyarakat penganut kepercayaan Sunda Wiwitan, meyakini bahwa alam sekitarnya telah memberikan manfaat bagi kehidupan manusia, sehingga tugas manusia untuk tetap menjaga dan melestarikan alam semesta untuk keberlangsungan hidup manusia. Nilai ini tercermin pada siswa menjadi terbiasa untuk menjaga keasrian dan kenyamanan di lingkungan kelas, sekolah, dan sekitarnya dengan menanam tanaman di pot bunga atau di halaman.

\section{SIMPULAN}

Berdasarkan uraian di atas maka dapat ditarik simpulan siswa SMA Negeri I Kawali dituntut untuk dapat memiliki kemantapan aqidah dan kekhusu'an ibadah (spriritual quotient), keluasan IPTEK (Intelegency quotient), dan keluhuran akhlak (emotional quotient). Hal ini, dapat buktikan pada proses pembelajaran diawali setiap kali masuk kelas sebagai pembuka pembelajaran, siswa selalu dibiasakan untuk berdo'a dan dilanjutkan dengan tadarus al-Qur'an secara bersama-sama. Begitu juga ketika pada saat sebelum pulang sekolah, siswa dibiasakan untuk berdo'a dan membaca Asmaul Husna secara bersama-sama serta sholat dzuhur berjamaah.

Kesulitan yang dihadapi guru: (1) Guru belum mengintegrasikan kearifan lokal sebagai sumber pendidikan karakter siswa dalam pembelajaran sejarah. (2) Kegiatan proses pembelajaran sejarah di dalam kelas kurang variatif karena masih menggunakan metode konvensional yaitu ceramah dan diskusi, sehingga siswa dalam menerima materi pelajaran sejarah kurang menarik, membosankan bahkan tidak termotivasi untuk berfikir kritis dan kreatif dalam pembelajaran sejarah. (3) media pembelajaran belum memanfaatkan lingkungan terdekat siswa seperti situs-situs, komunitas adat, dan kearifan lokal sebagai sumber belajar dan basis bagi pembentukan karakter siswa.

Pengembangan pendidikan nilai dengan memanfaatkan kearifan lokal pada masyarakat penganut kepercayaan Sunda Wiwitan untuk meningkatkan karakter siswa melalui integrasi dalam pembelajaran sejarah. Implementasikan pengembangan pendidikan nilai dengan memanfaatkan kearifan lokal pada masyarakat penganut kepercayaan Sunda Wiwitan dengan proses pembelajaran sejarah yang bersifat konstruktivisme. Dimana siswa akan mendapatkan pengetahuan tentang 
pentingnya menumbuhkan dan mengembangkan karakter melalui pengalaman sendiri dan melihat secara langsung pada masyarakat kepercayaan Sunda Wiwitan yang memiliki ajaran untuk memelihara keseimbangan hubungan antara manusia dengan sesamanya, lingkungan alamnya, dan Tuhannya. siswa memiliki nilai-nilai karakter sebagai berikut: religius, sosial, gotong royong, toleransi, dan peduli terhadap lingkungan untuk dimplementasikan dalam kehidupan sekolah, keluarga, dan masyarakat.

\section{UCAPAN TERIMA KASIH}

Ucapan terima kasih disampaikan kepada Rektor Universitas Galuh Dr. H. Yat Rospia Brata, Drs., M.Si., pihak SMA Negeri I Kawali Ciamis dan Masyarakat Penganut Kepercayaan Sunda Wiwitan di Dusun Susuru Desa Kertajaya Kecamatan Panawangan yang sudah memfasilitasi penelitian ini terlaksana dengan baik.

\section{DAFTAR PUSTAKA}

Cruickshank, Jenkin, D.B., \& Metcalf. K. (2006). The act of Teaching. New York: Mc Graw Hill.

Dick, W, Carey, L dan Carey, J.O. (2005). The Systematic Design of Instruction. New York : Pearson.

Garna, Judistira. (1994). "Masyarakat Tradisional Banten dan Upaya Pelestarian Nilai-Nilai Budaya", Makalah Seminar Puncak-Puncak Perkembangan Warisan Budaya Banten, Forum IImiah Festival Banten 1994. Serang, 28-29 Agustus 1994.

Hasan, S. H. (2003). Problematika Pendidikan Sejarah. Bandung: FPIPS UPI.

Hasanah, Aan. Dkk. (2015). Penanaman Nilai-Nilai Karakter Berbasis Kearifan Lokal Budaya Sunda Untuk Mengembangkan Life Skill Siswa Madrasah (Penelitian Pada Madrasah Aliyah Di Kota Bandung). Bandung: Penelitian Kompetitif Kolektif Direktorat Pendidikan Tinggi Islam Kementerian Agama Islam RI.

Hasanah, Aan. (2012). "Pengembangan Pendidikan Karakter Berbasis Kearifan Lokal Pada Masyarakat Minoritas ( Studi Atas Kearifan Lokal Masyarakat Adat Suku Baduy Banten)". Analisis. XII, (1), 209-228.

Indrawardana, Ira. (2014). "Berketuhanan Dalam Perspektif Kepercayaan Sunda Wiwitan". Melintas, 30, (1), HIm 109.

Kartakusuma, Richadiana (2006) 'Situs (Kabuyutan) Kawali di Ciamis, Jawa Barat: Ajaran Sunda di dalam TatananTradisi Megalitik', dalam Rosidi, Ajip dkk. (ed.) Prosiding Konferensi Internasional Budaya Sunda.

Khan, D. Yahya. (2010). Pendidikan Karakter Berbasis Potensi Diri. Yogyakarta : Pelangi Publising.

KIBS. (2006). Jilid 1. Bandung: Yayasan Kebudayaan Rancage.

Pribadi, Benny. (2009). Pendekatan Konstruktivisme Dalam Kegiatan Pembelajaran. Makalah telah disampaikan pada seminar Seamolec. IP FKIP-UT

Rasyid, Hatamar. (2015). "Nilai-Nilai Kearifan Lokal Dalam Pengembangan Pendidikan Karakter Di Era Global". Edugama. 01, (01), 1-31. 
Sariyatun. (2013). "Pengembangan Model Pendidikan Nilai-Nilai Budaya di SMP Berbasis Seni Batik Di Surakarta". Paramita. 23, (2), 230-241.

Sirnayatin, Ariska, Titin. (2017). "Membangun Karakter Bangsa Melalui Pembelajaran Sejarah”. Jurnal SAP. I, (03), 313.

Sondarika, W., \& Ratih, D. (2019). Pembelajaran Sejarah Dalam Mengembangkan Green Behavior Peserta Didik Melalui Nilai-Nilai Kearipan Lokal Hutan Lindung Situ Lengkong Panjalu. Jurnal Wahana Pendidikan, 6(2), 24-41.

Sumarmi dan Amirudin. (2016). "Kearifan Lokal Dalam Melestarikan Lingkungan Hidup (Studi Kasus Masyarakat Adat Desa Kemiren Kecamatan Glagah Kabupaten Banyuwangi)". Jurnal Pendidikan. 1, (4), 727. 